\title{
YIDDISH IN HELSINKI AND ITS SWEDISH COMPONENT
}

\author{
Simo MuIR \\ Helsinki \\ $-\infty-$
}

\section{INTRODUCTION*}

Yiddish has been spoken in Helsinki since 1850 s when the Jewish Cantonist soldiers and their families were allowed to settle in the town (Torvinen, 1989: 26-27). The first generations born in Helsinki had the possibility to attend beders and a talmud-torab where religious subjects were conducted in Yiddish (Weinstein, 1956: 24). In the wake of Yiddishizm many Yiddish-speaking societies were founded before and after the First World War (Weinstein, 1956: 35; Torvinen, 1989: Ir3). My research attempts an analysis of Helsinki Yiddish (hereafter HelY) and a survey of Yiddish culture in Helsinki. Previously no extensive study, according to my knowledge, has been undertaken to characterise Finnish Yiddish (hereafter FinY).

FinY is an amalgam of various North-Eastern Yiddish (hereafter NEY) subdialects, chiefly reflecting features of Stam-Litviš 'Yiddish of Lithuania Proper' and Courland Yiddish (on Yiddish dialects see Katz, I983; on NEY subdialects see Mark, I95I; Weinreich, I923). FinY itself can be divided into two subdialects since historically it has been under the influence of two different coterritorial languages, i.e. Finnish-Swedish (hereafter FS) in Helsinki and Turku (Torvinen, I989: III) and Finnish in Vyborg (Hartikainen, 1998: 75). Analysis of Vyborg Yiddish is undertaken by Jukka Hartikainen.

Swedish as a Germanic language has intermixed much more naturally with Yiddish than Finnish. Finnish influence in Helsinki Yiddish (hereafter HeIY) seems to be reflected only through FS. The similarity of languages also 
facilitated the shift from Yiddish to Swedish which happened relatively early many born in the r920s and 30 could not anymore understand Yiddish (Muir, 1999a: 8). FinY has also been influenced by modern German which was taught at schools. The German influence demonstrates itself chiefly lexically and morphologically whereas Swedish has also had a very strong phonetic impact. This paper concentrates on some aspects of the FS influence on HelY.

\section{Material}

The material used for this paper comprises both written and oral sources. I am presently conducting interviews of Yiddish speakers in Helsinki. By estimation there still are approximately hundred persons who can somehow communicate in Yiddish (Shapira, 1999). A very important document for my research is an interview of Moses Guthwert (1883-19--) arranged by Paul Ariste and Pentti Virtaranta in 1969. The written documents include: protocols of the Yiddish Literature Society 'Hatchijo' (I92I-I922), letters by the Jewish Congregation in Helsinki to Vyborg (1923-1940), two plays by Jac Weinstein (written around the turn of I920s and 30s) and articles in Hazohar-journal (1934-1939). The two latter sources are to a great extent written in latinized form, since there was no Hebrew print in Finland and also because the literacy of Yiddish and Hebrew was poor (Muir, 1999b: 6). These documents are of course interesting material for a phonetic study. All informants were born in Finland and most have at least one parent born or raised in Finland.

\section{Swedish Component}

Most Yiddish speakers in Helsinki have been bilingual. They have learned Swedish at school and from people they have been in contact with. Thus their Yiddish has been subject to some degree of interference from FS. According to Reuter (I977: 21, 26) FS differs phonetically from High Swedish (hereafter $\mathrm{HS}$ ) by reflecting Finnish influence and having preserved some archaic features.

The lexicon of Swedish and German overlaps in many cases and therefore occasionally it is difficult to unravel which language a loan word is from, for instance der fest 'celebration' (HS en fest, German der Fest), di kape 'robe' (HS en kappa, German die Kappe). The number of these kinds of loan words is large. Possibly the adaptation of a German word has been influenced by the existence of a similar word in Swedish. 
The similarity of certain Swedish, German and Yiddish words has made the spelling confusing, for instance word 'struggle' can be found on Hazohar's pages in all three forms: kamp (HS), kampf (German), kamf (Standard Yiddish, hereafter StY).

The following analysis has been compiled according to Rayfield's classifications of different interference patterns presented in his study The Languages of a Bilingual Community (I970: 54). They comprise five main categories: $\mathrm{x}$ ) phonetic interference, II) structural-phonetic interference, III) lexical interference, $\mathrm{rv}$ ) lexical-structural interference and v) structural interference.

Example words transcribed from interviews are in cursive, words transliterated from Hebrew characters have a circle [O] after the word and words in their original latinized form have a triangle $[\triangle]$ after the word.

\section{Phonetic Interference}

\section{Vowels}

The stressed vowels in HelY are often pronounced long. This phenomenon is especially interesting in the speech of those informants whose Yiddish resamples mostly the Štam-Litviš in which the vowels are pronounced short (Mark, I951: 440). According to Weinreich (I923: 199-200) Courland Yiddish has preserved the opposition between short and long vowels, for instance vowel $i$ is pronounced long in the word di bi:n meaning 'the bee' and short $i x$ bin in ' $\mathrm{I}$ am'. In HelY, however, the vowel of this example word in the latter reference may also be pronounced long, ix bi:n. This is most likely influenced by the HS pronunciation rule partly preserved in FS according to which the vowel of a stressed syllable is pronounced long or alternatively the following consonant geminates (Reuter, 1977: 30) (on geminates see point 3.I.2.).

FS has introduced into HelY some phonemes that are not used in StY and Stam-Litviš, i.e. vowels $\ddot{a}, \ddot{o}$ and $\ddot{u}$. In FS vowel $e$ is pronounced before $r$ as a very open and wide $\ddot{a}$ or $\ddot{a}$ : (Bergroth, 1928). This feature is strong and characteristic also for HelY, especially in stressed syllables, for instance ä:r lärnt di tejre 'he studies the Torah'. This can be seen to some extent in Est $Y$ as a case of Baltic German influence (Verschik, 1999: 277). In HelY $e$ before the guttural $x$ (Hebrew het and khaff) is pronounced as short $\ddot{a}$, for instance nextn>näxtn 'yesterday'. Also word plix 'bold' may be pronounced pläx.

As a result of mild interference the vowel $i$ may be pronounced as long or short $\ddot{u}$ in words, chiefly international, which in Swedish have ü-sound (spelled $y$ ), for instance tü:p 'type' (StY tip, HS typ), system $\triangle$ (StY sistem, HS system). Similarly long or short vowel $\ddot{o}$ can be encountered in stead of $e$ in some words due to FS influence, for instance inšenjö:r (StY inšenier, HS ingen- 
jör), religiös $\triangle(\mathrm{StY}$ religiez, HS religiös). These shifts could also be of German influence (compare with German Typ, System, religiös). However, Swedish influence seems to be more plausible at least in the case of $\ddot{u}$ since it appears quite systematically in words where the Swedish counterpart has $\ddot{u}$ and only very seldom when it appears in a native Germanic word, for instance words that are according to Verschik (1999: 272) pronounced in EstY with $\ddot{u}$, fünf 'five', grïn 'green', are pronounced normally in HelY - finf, grin.

The FS tr-sound (Reuter, 1977: 25) can be distinguished, for instance, in Swedish loan word sna:s 'snuff' and also in the hypercorrect pronunciation of jidišes ju:dise 'Jewish' (the word is spelled in German influenced orthography as judiše which coincides with the HS form judiska).

\section{Consonants}

The $\mathrm{r}$-sound in HelY is a lingual as in FS (Berghroth, 1928: 32) not uvular like in many Yiddish dialects. The l-sound is generally a soft alveolar as in FS (Reuter, 1977: 29). However, in Guthwert's speech there can be distinguished also a palatal 1-sound. In regards to the $\mathrm{r}$ - and l-sounds HelY seems to be similar with the CourlY and EstY sounds (Verschik, 1999: 276).

In HelY there is hardly any cases of typical sabesdiker losn, i.e. confusion of hissing and hushing consonants $s$ and $\check{s}$ (Mark, 195I: 436). However sibilant $\breve{s}$, voiced sibilant $z$ and affricate $c$ have been replaced by unvoiced sibilant $s$ in words where a similar Swedish word has s, for instance stel $>$ stel 'place' (HS ställe), zumer >sumer 'summer' (HS sommar), pelc >pels 'fur' (HS päls).

Consonant cluster $n g$ is generally pronounced as an n-sound as in FS, for instance lenger le $+e r$ 'longer', umgefer $>$ unefä: $r$ 'approximately' (HS ungefär).

Due to Swedish influence guttural $x$ is pronounced as $k$ in common words for both languages, for instance xarakter $>$ karakter $\triangle$ 'character' (HS karakter) and even bixer>bikär 'books' (HS böcker).

Geminating is very characteristic for HelY and it presumably takes its premises in the above-mentioned rule of Swedish language concerning stressed syllables. Geminating occurs with most consonants, for instance okoršt> okkorst 'just now', separat>seppara:t 'separate', farhejratet $>$ fe:rhejrretet 'married'. Geminating may also take place in a juncture of two words, for instance bert a majse>härtta majsse 'listen to this', hobn mir>hommi:r 'we have' (see Bergroth, 1928: 53). In EstY, for example, geminating is attested only in clusters of $k, p, t$ (Verschik, 1999, 277). 


\section{Structural-phonetic interference}

\section{Intonation}

Presently there is not sufficient material in order to draw conclusions of FS interference on HelY intonation. The interviews are not the best possible material for this, because they are chiefly monologues lacking the tempo and expressiveness of a casual conversation.

Rayfield notes that intonation patterns are imitated directly but also indirectly through imitation of constructions carrying with it certain features of stress (1977: 72). Bergroth describes FS speech as monotonous and less nuanced than HS (1928: 30). Possibly some of this is true also for HelY.

\section{Stress on International Words}

The FS way of pronouncing of some international words interferes very much with the Yiddish pronunciation. The stress of the word, which in Yiddish is usually on the first or second syllable, moves in most cases to the last syllable. In addition some structural changes take place, i.e. the suffix of the word changes slightly or completely. All these features manifest themselves also in spelling which follows the Swedish orthography.

\begin{tabular}{|c|c|c|c|}
\hline Change $\mathrm{StY}>\mathrm{HelY}$ & Pronunciation & Spelling & English \\
\hline -cie>-čiun & fúnkcie> funkču:n & funkcie> funkcion 0 & function \\
\hline -gie>-gion [jún] & - & religie>religion 0 & religion \\
\hline$-g i e>-s ̌ i$ & enérgie>enerši: & energie >nergi $\triangle$ & energy \\
\hline$-i e>i$ & - & diplomátie>diplomati $\triangle$ & diplomacy \\
\hline$-i e>-$ & families $>$ fami:l & - & family \\
\hline$-e t>-\dot{e}$ & komitét>komite: & komitet $>$ komite $\bigcirc$ & committee \\
\hline$-e j>-e^{\prime}$ & armeij>arme: & 一 & army \\
\hline$-i e r>-j o ̈: r$ & akompánier>akompanjö:r & - & accompanist \\
\hline -er>árie & - & bibliotéker>bibliotekarie 0 & librarian \\
\hline$\rightarrow-u m$ & cénter>céntrum & - & centre \\
\hline
\end{tabular}

\section{Lexical Interference}

In the lexicon of HelY, especially in written documents, the Semitic and Slavic component is minor. The Slavic component has always been small in the Yiddish dialects of the Balticum. The percentage of Slavic and Semitic component in Hatchijo's protocols is less than $\mathrm{I} \%$. In the place of these words native Yiddish words of Germanic origin and German or Swedish loans occur. This tendency was deliberate among the young in I920s (Muir, I999b: 19). However the number of Swedish words in the lexicon is low. 


\section{Loan Words}

Here is a list of some Swedish words found in HelY. Some of them are loan words already in Swedish.

\begin{tabular}{|c|c|c|c|}
\hline $\begin{array}{l}\text { HelY } \\
\text { stadgar } 0\end{array}$ & $\begin{array}{l}\underline{\mathrm{HS}} \\
\text { stadgar }\end{array}$ & $\begin{array}{l}\text { StY (Weinreich, I977) } \\
\text { takones }\end{array}$ & $\begin{array}{l}\underline{\text { English }} \\
\text { statutes }\end{array}$ \\
\hline der kapsek $\triangle$ & en kappsäck & di valize & suitcase \\
\hline di samantrede $\bigcirc$ & ett sammanträde & di asife & meeting \\
\hline bandelsbitreden 0 & handelsbiträde & gešeft-gehilfn & shop assistants \\
\hline di skulkassa $\bigcirc$ & en skolkassa & di škole-kase & school fund \\
\hline - tevling, -en $\bigcirc$ & en tevling, -ar & der farmest & contest, $-\mathrm{s}$ \\
\hline - reduvisning $\circ$ & en redovisning & der barixt & account \\
\hline - histori:k & en historik & di gešixte & history, survey \\
\hline - sült & sylt, -en & di varenie & jam \\
\hline$-\sin \pi \cdot s$ & snus, -et & der šmek tabik & snuff \\
\hline gratis 0 & gratis & bexinom & for nothing \\
\hline $\operatorname{adjö} \triangle$ & adjö & a gutn & good by \\
\hline
\end{tabular}

\section{Loan Blends}

A loan blend is a compound word of which one element is native and the other borrowed (Rayfield, 1970: 60), for instance planbuch $\triangle$ 'wallet' (HS plån 'plate', StY bux 'book'), frage biro $\mathrm{O}$ 'information bureau' (StY frage 'question', HS byrå 'bureau'). Some institutions and associations are called by their Swedish names with Yiddish attributes, for instance texniše lä:rovärk 'College of Technology', ju:diše sonföre:ning 'Jewish Song Association'.

\section{Loan Shifts}

A loan shift is a case where a word of one language changes its meaning under the influence of a word in the other language which is partly synonymous with it (Rayfield, 1970: 60). An example of this is the StY word farzamlung 'meeting', which by Swedish influence has extended its meaning to 'congregation' (HS församling), for instance di idiš ferzamlung $O$ 'the Jewish congregation' instead of StY di jidiš gemejnde.

\section{Loan Translations}

The Yiddish preposition $c u$ 'to' is used frequently in the manner of Swedish till, for instance men hot telefonirt cu her bolotovski $O$ 'a phonecall was made to Mr. Bolotovski' (HS man telefonerade till herr Bolotovski and StY men bot telefonirt ber bolotovskin). 


\section{Lexical-structural Interference}

Most Swedish loan words adapt easily to the morphology of Yiddish and inflect with same affixes as native words. The plural for tevling 'contest' is tevlingen not tevlingar as in Swedish. The Yiddish plural forms resample the Swedish definite singular and plural forms of the words.

There seems to be no regularity in assigning a Swedish loanword to any particular gender and sometimes the definite article is omitted altogether, for instance forzicender kac bot ojfgegeben _ reduvisning far dem komitet $O$ 'chairman Katz gave the account to the committee' (StY forzicer kac hot ojfgegebn dem barixt far dem komitet). This is most likely caused by the fact that Swedish definity is partly indicated with suffixes. Similar tendency according to Verschik (r999: 280) can be seen in EstY as an influence from Estonian.

Adjectives borrowed from Swedish inflect also normally, for instance kejn andere förnuftige alternative $\triangle$ 'no other reasonable alternative' (HS förnuftig, StY sejxldike), af aza nonšalantn ojfn $O$ 'in such a nonchalant manner' (HS nonchalant, StY glajxgiltikn). Loan verbs adapt also well, for instance prenumeriren $O$ 'to subscribe' (HS prenumerera, StY abonirn), šustirn $O$ 'confirm' (HS justera, StY baštetikn).

\section{Structural Interference}

\section{Borrowing of Function Words}

The Swedish preposition fran 'from' is phonetically very similar with its Yiddish equivalent fun and occasionally can be encountered, for instance fron Rusland 'from Russia'. Preposition fun meaning 'of something' may be replaced by Swedish av, for instance a lä:rer a:v ivrit 'a Hebrew teacher'. Personal pronoun zei they' may be replaced with Swedish dom, for example far dom 'for them'. The Swedish interrogative pronoun vern 'who/m' can be encountered instead of the "longer" Yiddish variant vemen, for instance far vem $\triangle$ 'for whom'.

\section{Borrowing of Construction}

Yiddish and Swedish have a similar word order regarding the rule of placing the inflected verb in the second position within a sentence. However the place of negator in a subordinate clause is different since in Swedish it is before the inflected verb and in Yiddish after it. This may interfere with the Yiddish word order, for instance mitglider velxe nit hoben becolt $O$ 'members who have not paid' (HS medlemmar som inte har betalat, StY mitglider velxe hobn nit bacolt). 
The article may be omitted also from native Yiddish words. According to Wolf (1969: I23) this is common in NEY especially after nasal prepositions, fun 'from' and in 'in'. However in HelY the article may be left out also after non-nasal prepositions, for instance program $\mathrm{Cu}$ _ algemejner ferzamlung $\mathrm{O}$ 'program for the general meeting' (HS programmet för almänna församlingen, $\mathrm{StY}$ program culfar der algemejner farzamlung). Also words in direct object position may occur without an article, for instance men hot šustirt _ protokol $O$ 'the protocol was confirmed' (StY men hot baštetikt dem protokol). This happens more frequently with words common for both languages. Swedish influence has obviously increased the omission of the definite article since, as earlier stated (3.4.), in Swedish the definity is expressed by suffixes, hence the latter sentence in Swedish would read: man justerade protokollen.

The fact that a word may appear in one person's speech with different articles, for instance derldi bime 'bimah' (StY di bime), derldi protokol 'protocol' (StY der protokol). manifests further the decline of the system. According to Mark (I95I: 452) this phenomenon is characteristic for NEY. It is peculiar that occasionally in HelY the masculine definitive article does not inflect at all, for instance rede fun der forzicender $\mathrm{O}$ 'speech of the chairman' ( $\mathrm{St} \mathrm{Y}$ di rede fun dem forzicer). Again one possible reason for this phenomenon is found from Swedish where definite articles (det, den) do not inflect at all.

\section{Minor Structural Features}

The occurrence of suffix $-t$ with adverbs can be considered as a minor structural feature of Swedish influence, for instance speciel>spesielt 'specially' and relativ>relati:vt 'relatively'. However this seems to apply only to words that are similar in Yiddish and Swedish.

\section{Conclusion}

The over hundred years of coexistence with FS has given HelY its own distinctive charter, which deserves to be recorded and studied. Especially unique is the interference of Swedish morphology with its peculiarities. Hopefully a research is conducted on Swedish Yiddish as it would be interesting to see whether similarities exist with HelY.

\section{Notes}

* I would like to thank the Finnish Cultural Foundation for financing my research of Yiddish language and culture in Helsinki. 


\section{BibliogRaPHY}

\section{Books and Articles}

Bergroth, H. 1928. Finlandssvenska, Handledning till undvikande av provinsialismer $i$ tal och skrift. Mercators tryckeri aktiebolaget, Helsinki.

Hartikainen, J. 1998. "Viipurin juutalaisen yhteisön vaiheita". In Kuujo E. (ed.) Viipurin suomalaisen kirjallisuusseuran toimitteita, no. 13. Lappeenrannan kirjapaino Oy, Helsinki. pP.5I-I2I.

Katz, D. 1987. Grammar of the Yiddish Language. Duckworth, London.

Katz, D. 1983. "Zur Dialektologie des Jiddischen". In W. Besch Dialektologie, Ein Handbuch zur deutschen und allgemeinen Dialektforschung. Walter de Gruyter, Berlin, New York. pp. ror8-104I.

Mark, Y. 1951. "Undzer litvišer jidiš". In M. Sudarski, Lite. New York. pp. 492-472.

Muir, S. I999. Jac Weinstein and the Jewish Drama Society in Helsinki during the Interim of the World Wars (Unpublished dissertation for MA in Yiddish Studies, University of London). London.

Muir, S. 1999(b) Jiddišismiä Helsingissä, Yidisher literaturfarein 'Hatchijo' ja kansallisromanttisia runoja, (Unpublished seminar paper, Institute for Asian and African Studies, University of Helsinki). Helsinki.

Rayfield, J.R. 1970. The Languages of a Bilingual Community. Mouton, The Hague, Paris.

Reuter, M. 1977. "Finlandssvenskt uttal". In B. Petterson and M. Reuter Språk och språkvård. Holger Schildts Förlag, Helsinki. pp. 19-57.

Weinreich, M. 1923. "Dos kurlender jidiš". In Štaplen, Fir etjudn cu der jidišer špraxvisnšaft, literatur, gešixte. Berlin. pp. 193-240.

Weinreich, M. 1977. Modern English-Yiddish, Yiddish-English Dictionary. Schocken Books, New York.

Weinstein, J. 1956. Minnesskrift till so-årsdagen av Judiska församlingens $i$ Helsingfors synagogas invigning, del I och II. Helsinki.

Verschik, A. 1999. "The Yiddish Dialect in Estonia (a Description)". In Fenno Ugristica, Vol. 22, Indo-European-Uralic-Siberian Lingusitics and Cultural Contacts. Tartu University Press, Tartu. pp. 265-291.

Wolf, M. 1969. "The Geography of Yiddish Case and Gender Variation". In M. Herzog, The Field of Yiddish, Studies in Language, Folklore and Literature. Mouton \& Co, London. pp. IO2-2I5

\section{Interviews}

Shapira, E. r998. Interview by S. Muir. Kotimaisten kielten nauhoitearkisto.

\section{SAMMANFATTNING}

Denna uppsats baseras på preliminära iakttagelser av finlandssvenskans inflytande på Helsingfors-jiddischen och är del av en större studie av Helsingfors-jiddischens ursprung och hur den påverkats genom historien. Jiddisch 
har talats i Helsingfors sedan sedan 1850-talet när soldater ur den ryska armén efter avsked började bosätta sig i staden tillsammans med sina familjer. Dessa soldater och immigranter talade i första hand olika nordöstliga, primärt litauiska, jiddischdialekter. I Helsingfors kom de att bosätta sig i områden där finlandssvenskan dominerade, medan det i Vyborg var finskan som var huvudspråk.

Artikeln innehåller analyser av olika influenser, t. ex. inom fonetik, ordförråd och strukturer, vilka kan påträffas i tal- och skriftspråk. Uttalen av både vokaler och konsonanter har påverkats; finlandssvenskan har också bidragit med fonem som normalt inte finns i jiddisch, såsom ä, ö, ü, och u. Man märker till en exempel en stark trend att uttalet av internationella ord, som finns i båda språken, blir det svenska. Vad gäller låneorden är det ibland svårt att avgöra om lånet kommer från svenskan eller tyskan och de rena inlånen från svenskan är få till antalet. Låneorden böjs oftast som vanliga jiddischord. I fråga om ord i bestämd form framträder det svenska böjningsmönstret på bekostnad av jiddischens bestämda artiklar och deras former. 